\title{
MILK PASTEURIZATION USING SOLAR CONCENTRATOR WITH TRACKING DEVICE
}

\author{
Atia, M. F. ${ }^{3}$; M. M. Mostafa ${ }^{1}$; M. A. El-Nono ${ }^{1}$ and \\ M. F. Abdel-Salam ${ }^{2}$
}

ABSTRACT

Milk pasteurization process consumes a large amount of energy, using of solar energy for pasteurization process reduces the required conventional energy. Experimental study was conducted to equip a solar concentrator with dual axis sun tracking device and utilizing it for milk pasteurization. The tracking device was a closed-loop system, it was worked based on the contrast of sunlight levels using light-dependent resistors (LDRs) and opamp chip. The thermal system was comprised of solar parabolic dish, energy conversion subsystem, and heat exchanger. The system was able to pasteurize about $260 \mathrm{ml}$ of milk at $73{ }^{\circ} \mathrm{C}$ in average time 110 seconds. The average hourly productivity of solar pasteurized milk was about 7.5 liters. The tracking device was able to track the motion of sun and keep the solar concentrator in a straight axis to the sun, and it had a feature of the low cost. The results indicated that the tracking device was led to increase of the cumulative daily heat gain by approximately $59 \%$. The temperature of the absorber plate was reached $190{ }^{\circ} \mathrm{C}$ with the automatic tracked concentrator while it was $91{ }^{\circ} \mathrm{C}$ with the non-tracked on March 2016.

\section{INTRODUCTION}

ilk pasteurization process is aimed to kill the harmful
microorganisms in milk using the heating at temperature of
$73^{\circ} \mathrm{C}$ for 15 seconds. The one ton of liquid milk is consumed about $40 \mathrm{kWh}$ for pasteurization process, Niamsuwan et al. (2011). The yearly production of milk in Egypt is about 5 MT (Million Tons), ElShebley et al. (2003). Utilizing of solar energy for milk pasteurization in Egypt may lead to save about $200 \mathrm{GW} /$ year of electricity or $80 \times 10^{3}$ $\mathrm{m}^{3} /$ year of oil fuel.

\footnotetext{
${ }^{1}$ Emt. Prof. of Agric. Eng. Dept., Fac. of Agric., Ain Shams University.

${ }^{2}$ Assist. Prof. of Agric. Eng. Dept., Fac. of Agric., Ain Shams University.

${ }^{3}$ Assist. Lecturer of Agric. Eng. Dept., Fac. of Agric., Ain Shams University.
} 
Egypt is located in the areas where solar energy is abundant. The solar radiation on Egypt ranges from 5 to $8 \mathrm{kWh} / \mathrm{m}^{2}$ per day with about 3500 sunshine hours per year, Sorensen (2003).

The abundance of solar energy in Egypt paired with the concept of milk pasteurization may be a good alternative to achieve environment conservation, ensure healthy milk, and address the problem of energy and reduce cost of energy.

ASHRAE (1995) reported that, the solar energy collectors are special kind of heat exchangers that transform solar radiation energy to internal energy of the transport medium. Rauta and Singh (2009) showed that, the solar collector can be classified to non-concentrated and concentrated, it may be of the following types; flat plate collector, parabolic trough, parabolic dish, fresnel lens, or heliostats. Kalogirou et al. (1994) stated that, concentrating systems exhibit certain advantages as compared with the conventional flat plate type.

Biari (1990) stated that, the concentrator systems will not work efficiently without sun tracking, so at least single axis tracking is required; this is as a result of the continuous changing of sun position with respect to time of the day. He reported the amount of solar energy captured by a tilted collector could be increased by more than $40 \%$ by adjusting the tilt angle.

The power produced by concentrated solar thermal system is directly related to the amount of solar energy acquired by the system, and it is necessary to track the sun position. The sun tracking systems can be classified to closed-loop and open-loop. Closed-loop types are based on feedback control principles; in these systems, a number of inputs are transferred to a controller from sensors which detect relevant parameters induced by the sun. While the open-loop type of controller computes its input into a system using only the current location state and the algorithm of the system without using feedback to determine if its input has achieved the desired goal or no, Lee et al. (2009).

Braun and Mitche (1983) evaluated theoretically the sun zenith, sun azimuth, surface azimuth and slope angles for one axis and dual axis sun trackers, they found radiation beam is maximized when surface azimuth is equal to sun azimuth and the surface slope is equal to zenith. 
Mousazadeh et al. (2009) stated that, the sun's coordinates for sun tracking systems are; elevation angle which is the angle between the tracking location on the earth to the sun (in the vertical plane), and azimuth angle which is the angle between true north of tracking location and the direction of the sun (in the horizontal plane),

Zahira et al. (2009), Atia et al. (2010) and Wayua et al. (2013) have utilized the flat plate collectors for milk pasteurization. Franco et al. (2007) have pasteurized the milk using non-tracked solar concentrator.

The specific aims of this research:

- to utilize of solar concentrator for milk pasteurization;

- to equip the solar concentrator with sun tracking device;

- to characterize the whole system;

- to analyze the performance of the system.

\section{MATERIALS AND METHODS}

A solar milk pasteurizer was constructed and installed in Department of Agricultural Engineering, Faculty of Agriculture, Ain Shams University, Shoubra El-Kheima, Egypt (Latitude $30^{\circ} 06^{\prime} \mathrm{N}$, Longitude $31^{\circ} 14^{\prime} \mathrm{E}$ ) where the solar radiation and ambient temperature ranged from 400 to $1050 \mathrm{~W} / \mathrm{m}^{2}$ and 23 to $38^{\circ} \mathrm{C}$, respectively, during the study period.

The constructed system is shown in Fig. (1), it consists of four main components; solar concentrator, heat absorber, heat exchanger, and raw milk tank.

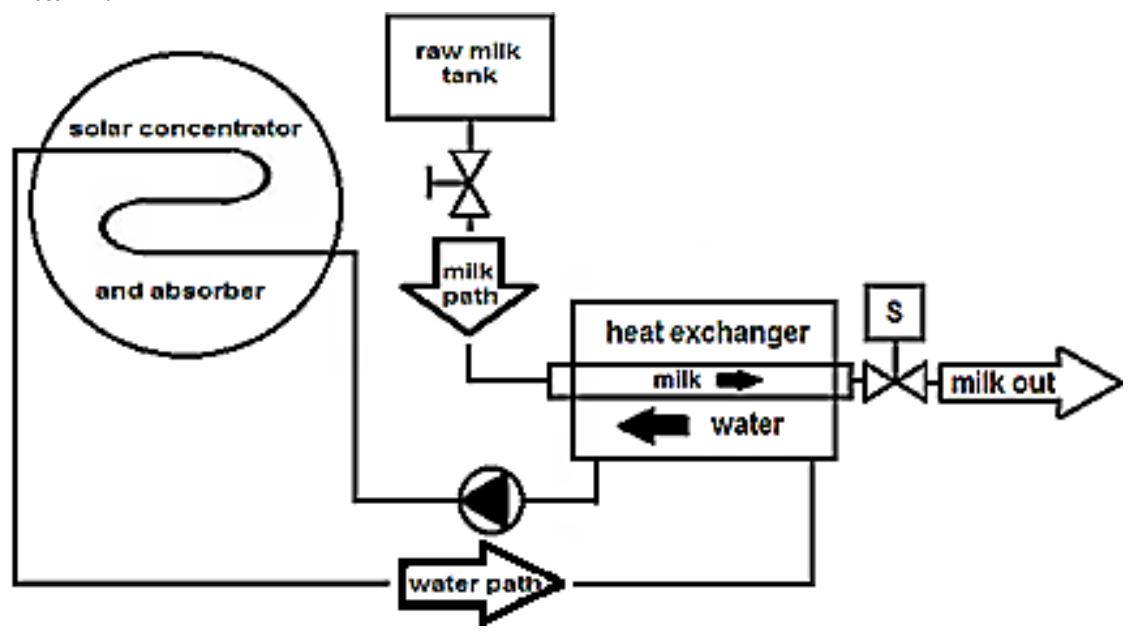

Fig. (1): Diagram of the constructed system for milk pasteurization by solar energy. 


\section{The solar concentrator and absorber:}

The solar concentrator was a parabolic dish, a satellite dish was employed for this purpose, its interior surface was covered with solid segments of polished stainless steel in order to be a reflective surface. As shown in Fig. (2), the main geometrical parameters of the parabola are; opening diameter (D), depth (h) and the focal length (f). The characteristics of the solar concentrator are shown in Table (1).

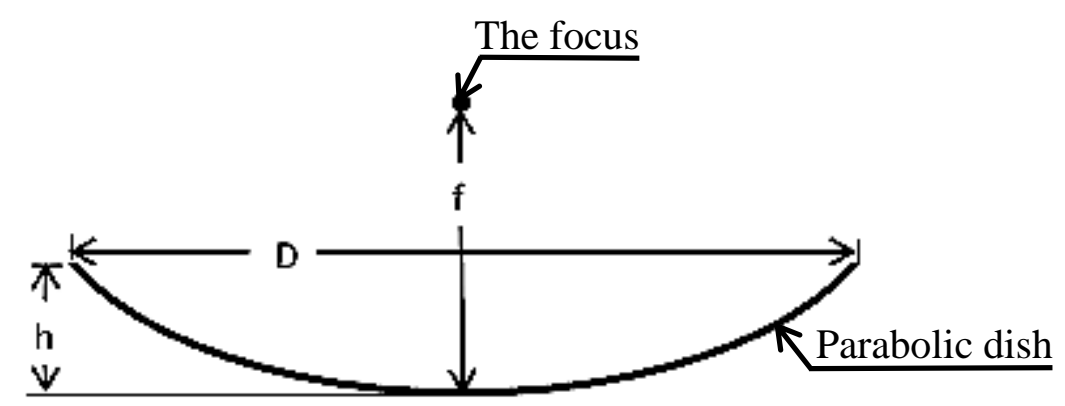

Fig. (2): Geometrical parameters of the parabola.

The absorber was placed in the focal zone of the parabolic dish faced the reflective surface, it was made of matt black painted square aluminum plate which was contacted with matt black painted copper tube which was formed to serpentine shape as shown in Fig. (3). The absorber was boxed by aluminum case, the rear and sides were insulated by $25 \mathrm{~mm}$ wool glass. The characteristics of the absorber are shown in Table (1).

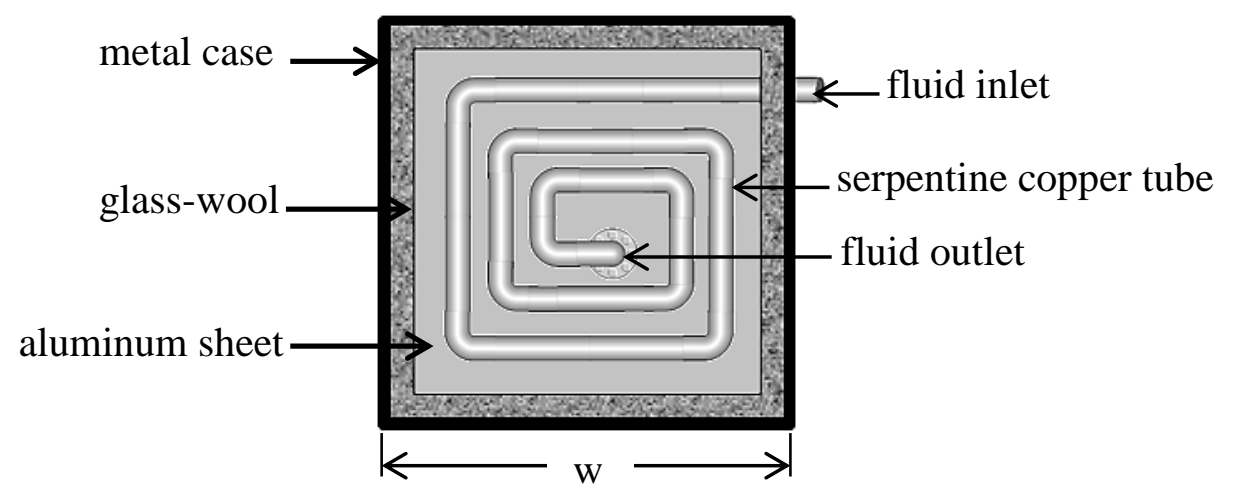

Fig. (3): Plan view of the absorber.

The geometrical parameters of the parabola are given by the following equations (William and Raymond, 1985):

The focal length of parabola is given by: 


$$
f=\frac{D^{2}}{16 h}
$$

The aperture area of the opening parabola $\left(\mathrm{A}_{\mathrm{c}}\right)$ is given by:

$$
A_{c}=\frac{\pi D^{2}}{4}
$$

The geometrical concentration ratio $\left(\mathrm{CR}_{\mathrm{g}}\right)$ is given by:

$$
C R_{g}=\frac{A_{c}}{A_{a}}
$$

where: $\left(\mathrm{A}_{\mathrm{a}}\right)$ is the lighted area of the absorber.

The overall thermal efficiency $\left(\eta_{0}\right)$ of the solar concentrator is defined as the ratio of the useful heat energy to the solar radiation falling on the concentrator aperture. Thus the thermal performance can be calculated by the following equations (Kalogirou 2004 and ASHREA 2005):

where:

$$
\mathrm{Q}_{\mathrm{s}}=\mathrm{I}_{\mathrm{s}} \cdot \mathrm{A}_{\mathrm{c}}
$$

$\mathrm{Q}_{\mathrm{s}}$ : received solar energy by the concentrator aperture, $(\mathrm{W})$;

$\mathrm{I}_{\mathrm{s}}$ : incident solar radiation on the concentrator aperture, $\left(\mathrm{W} / \mathrm{m}^{2}\right)$;

$\mathrm{A}_{\mathrm{c}}=$ aperture area of solar concentrator, $\left(\mathrm{m}^{2}\right)$.

And,

where:

$$
\mathrm{Q}_{\mathrm{u}}=\mathrm{mC} \Delta \mathrm{T}
$$

$\mathrm{Q}_{\mathrm{u}}$ : the useful energy gained in the working fluid, (W);

$\mathrm{m}$ : mass flow rate of the working fluid, $(\mathrm{kg} / \mathrm{s})$;

$\mathrm{C}$ : specific heat of the working fluid, $(\mathrm{J} / \mathrm{kg} \mathrm{K})$;

$\Delta \mathrm{T}$ : difference between inlet and outlet temperatures, $(\mathrm{K})$.

Thus,

\section{The heat exchanger:}

$$
\eta_{\mathrm{o}}=\frac{\mathrm{Q}_{\mathrm{u}}}{\mathrm{Q}_{\mathrm{s}}}
$$

A countercurrent flow double pipe heat exchanger was constructed. As shown in Fig. (4), it consists of two concentric stainless steel tubes. The hot water flows in the annulus tube which has an outer diameter $\left(D_{a 0}\right)$, while the milk flows in the opposite direction through the inside tube which has an outer diameter $\left(D_{i o}\right)$. The heat exchanger was manufactured by argon gas welding. The characteristics of the heat exchanger and the working fluids are shown in Table (1). 


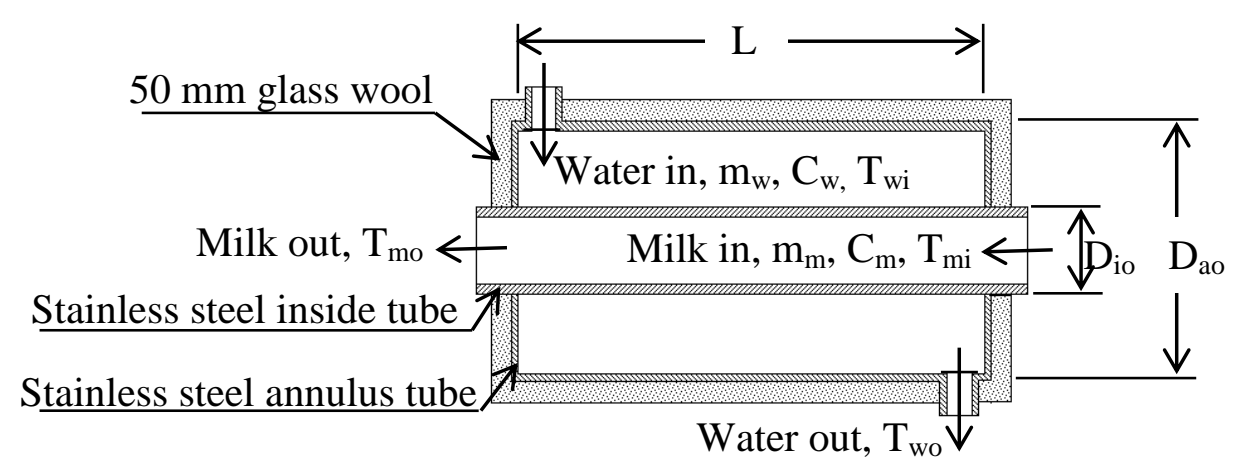

Fig. (4): Longitudinal section of the heat exchanger.

The heat transfer process in the heat exchanger can be described as follows, corresponding to (Bergman et al., 2011);

As shown in Fig. (4), the rate of heat transfer in the exchanger assuming heat losses from the outer tube stream to be negligible. Therefore the rate of heat transfer (Q) is equal to either the released heat from the water stream or the absorbed heat by the milk stream, according to the following heat balance equation:

where:

$$
Q=m_{w} C_{w}\left(T_{w i}-T_{w o}\right)=m_{m} C_{m}\left(T_{m o}-T_{m i}\right)
$$

Q: rate of heat transfer $(\mathrm{W})$;

$\mathrm{m}_{\mathrm{w}}, \mathrm{m}_{\mathrm{m}}$ : mass flow rate of water and milk, respectively, $(\mathrm{kg} / \mathrm{s})$;

$\mathrm{C}_{\mathrm{w}}, \mathrm{C}_{\mathrm{m}}$ : specific heat of water and milk, respectively, $(\mathrm{J} / \mathrm{kg} \mathrm{K})$;

$\mathrm{T}_{\mathrm{wi}}, \mathrm{T}_{\mathrm{mi}}$ : inlet temperature of water and milk, respectively, $(\mathrm{K})$;

$\mathrm{T}_{\mathrm{wo}}, \mathrm{T}_{\mathrm{mo}}$ : outlet temperature of water and milk, respectively, $(\mathrm{K})$.

The rate of heat transfer can also be expressed as:

$$
Q=U A \Delta T_{m}
$$

where:

$\mathrm{U}$ : overall heat transfer coefficient, $\left(\mathrm{W} / \mathrm{m}^{2} . \mathrm{K}\right)$;

A: surface area of the heat exchanger, it's given by $\left(\pi \mathrm{D}_{\mathrm{ai}} \mathrm{L}\right),\left(\mathrm{m}^{2}\right)$;

$\Delta \mathrm{T}_{\mathrm{m}}: \log$ mean temperature difference, $(\mathrm{K})$, it's given by:

$$
\Delta T_{m}=\frac{\Delta T_{1}-\Delta T_{2}}{\ln \left(\frac{\Delta T_{1}}{\Delta T_{2}}\right)}
$$

where: $\Delta \mathrm{T}_{1}$ and $\Delta \mathrm{T}_{2}$ represent the temperature difference between the two fluids at the two ends (inlet and outlet) of the heat exchanger, as shown in Fig. (5). 


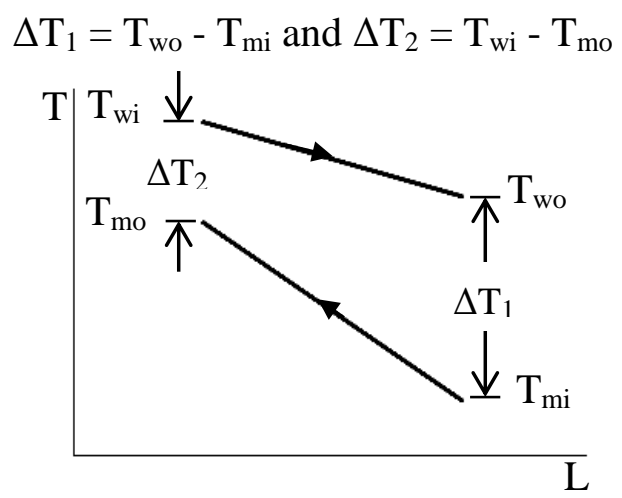

Fig. (5): The temperature profile of the heat exchanger.

As shown in Fig. (6), the heat stream overcomes three thermal resistances in order to flows from hot water to cold milk through the cross-section of the exchanger; the convection resistance of the outside flow (water), the conduction resistance of the tube thickness (stainless steel), and the convection resistance of the inside flow (milk). The sum of these thermal resistances can be introduced as the overall heat transfer coefficient (U), it's given by:

$$
\frac{1}{U}=\frac{1}{h_{w}}+\frac{\ln \left({ }^{r_{o}} / r_{i}\right)}{2 \pi k L}+\frac{1}{h_{m}}
$$

where:

$\mathrm{h}_{\mathrm{w}}$ : convective heat transfer coefficient of water, $\left(\mathrm{W} / \mathrm{m}^{2} . \mathrm{K}\right)$;

$\mathrm{h}_{\mathrm{m}}$ : convective heat transfer coefficient of milk, $\left(\mathrm{W} / \mathrm{m}^{2} . \mathrm{K}\right)$;

$\mathrm{k}$ : thermal conductivity of the tube material, $(\mathrm{W} / \mathrm{m} \mathrm{K})$;

$\mathrm{r}_{\mathrm{o}}, \mathrm{r}_{\mathrm{i}}$ : outer and inner radius of the inside tube, respectively, $(\mathrm{m})$.

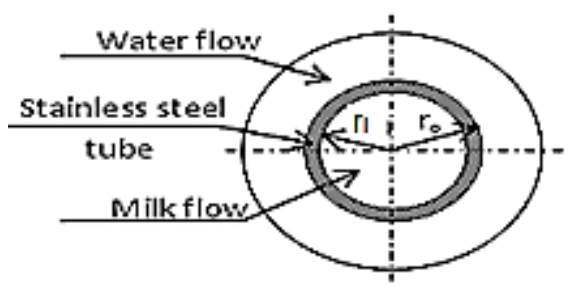

(a)

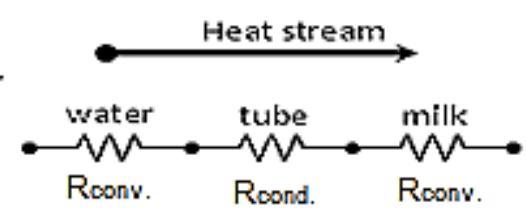

(b)

Fig. (6): a: cross-section of the exchanger, b: the thermal resistance network of the exchanger. 
Table 1: Characteristics of the constructed system:

\begin{tabular}{|c|c|c|c|}
\hline \multicolumn{2}{|c|}{ 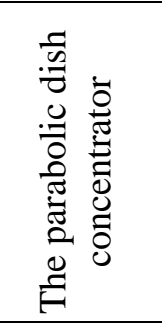 } & $\begin{array}{l}\text { The opening diameter }(\mathrm{D}) \\
\text { Aperture area }\left(\mathrm{A}_{\mathrm{c}}\right) \\
\text { Depth }(\mathrm{h}) \\
\text { Focal length } \\
\text { Material of the reflector cover } \\
\text { Reflection coefficient } \\
\text { Concentration ratio } \mathrm{CR}_{\mathrm{g}}\end{array}$ & $\begin{array}{l}1.45 \mathrm{~m} \\
1.65 \mathrm{~m}^{2} \\
0.19 \mathrm{~m} \\
0.69 \mathrm{~m} \\
\text { Polished stainless steel } \\
0.85 \\
40 \\
\end{array}$ \\
\hline \multirow[b]{2}{*}{ 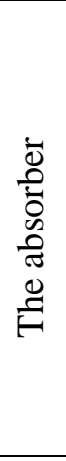 } & plate & $\begin{array}{l}\text { Width (w) } \\
\text { Thickness } \\
\text { Material } \\
\text { Absorbance }\end{array}$ & $\begin{array}{l}0.3 \mathrm{~m} \\
0.002 \mathrm{~m} \\
\text { Matt black painted aluminum } \\
0.96\end{array}$ \\
\hline & tube & $\begin{array}{l}\text { Outer diameter } \\
\text { Thickness } \\
\text { Serpentine length } \\
\text { Material } \\
\text { Thermal conductivity of copper } \\
\text { Working fluid }\end{array}$ & $\begin{array}{l}0.016 \mathrm{~m} \\
0.001 \mathrm{~m} \\
2.37 \mathrm{~m} \\
\text { Matt black painted copper } \\
385 \mathrm{~W} / \mathrm{m} \mathrm{K} \\
\text { Water }\end{array}$ \\
\hline & $\frac{n}{z}$ & $\begin{array}{l}\text { Length of the heat exchanger } \\
\text { Outer diameter of annulus tube }\left(D_{\mathrm{ao}}\right) \\
\text { Inner diameter of annulus tube }\left(\mathrm{D}_{\mathrm{ai}}\right) \\
\text { Material } \\
\text { Thermal cond. of stainless steel }(\mathrm{k}) \\
\text { Fluid in the annulus tube } \\
\text { Water volume } \\
\text { Water density }\left(\rho_{\mathrm{w}}\right) \\
\text { Specific heat of water }\left(\mathrm{C}_{\mathrm{w}}\right) \\
\text { Outer diameter of inside tube }\left(\mathrm{D}_{\mathrm{io}}\right) \\
\text { Inner diameter of inside tube }\left(\mathrm{D}_{\mathrm{ii}}\right) \\
\text { Material } \\
\text { Fluid in the inside tube } \\
\text { Milk volume } \\
\text { Milk density }\left(\rho_{\mathrm{m}}\right) \\
\text { Specific heat of milk }\left(\mathrm{C}_{\mathrm{m}}\right)\end{array}$ & $\begin{array}{l}0.78 \mathrm{~m} \\
0.076 \mathrm{~m} \\
0.072 \mathrm{~m} \\
\text { Stainless steel } \\
16 \mathrm{~W} / \mathrm{m} \mathrm{K} \\
\text { Water } \\
2.84 \mathrm{liters} \\
1000 \mathrm{~kg} / \mathrm{m}^{3} \\
4.18 \mathrm{~kJ} / \mathrm{kg} \mathrm{K} \\
0.022 \mathrm{~m} \\
0.02 \mathrm{~m} \\
\text { Stainless steel } \\
\text { Milk } \\
0.24 \mathrm{liters} \\
1030 \mathrm{~kg} / \mathrm{m}^{3} \\
3.93 \mathrm{~kJ} / \mathrm{kg} \mathrm{K}\end{array}$ \\
\hline
\end{tabular}

\section{The applied methodology for milk pasteurization by solar energy:}

In this investigation, the process of milk pasteurization by solar energy can be partitioned into two separated loops; one of both is a closed loop system for water heating, the other one is an open loop system for milk heating. The two loops become in contact inside the heat exchanger as shown in Fig. (7). 
The solar concentrator reflects and concentrates the sun rays on the absorber where transforms it into heat energy, then the heat transfers to the water which slowly flows in the copper serpentine. The water is heated up and flows out to the heat exchanger where the hot water heats up the cooler water. The resulting water is returned to the absorber for more heating up, and so on. The flow rate of water is regulated with valves and flow meter.

Once the water temperature in the heat exchanger reaches $90{ }^{\circ} \mathrm{C}$, the valve is fully opened to let the milk to flow from into the inside tube of the heat exchanger. The milk absorbs the heat released by the hot water. When the milk temperature reaches the desired pasteurization temperature $73{ }^{\circ} \mathrm{C}$, a solenoid valve opens to let the milk out. The solenoid valve is controlled by a temperature controller which senses the temperature of milk in heat exchanger.

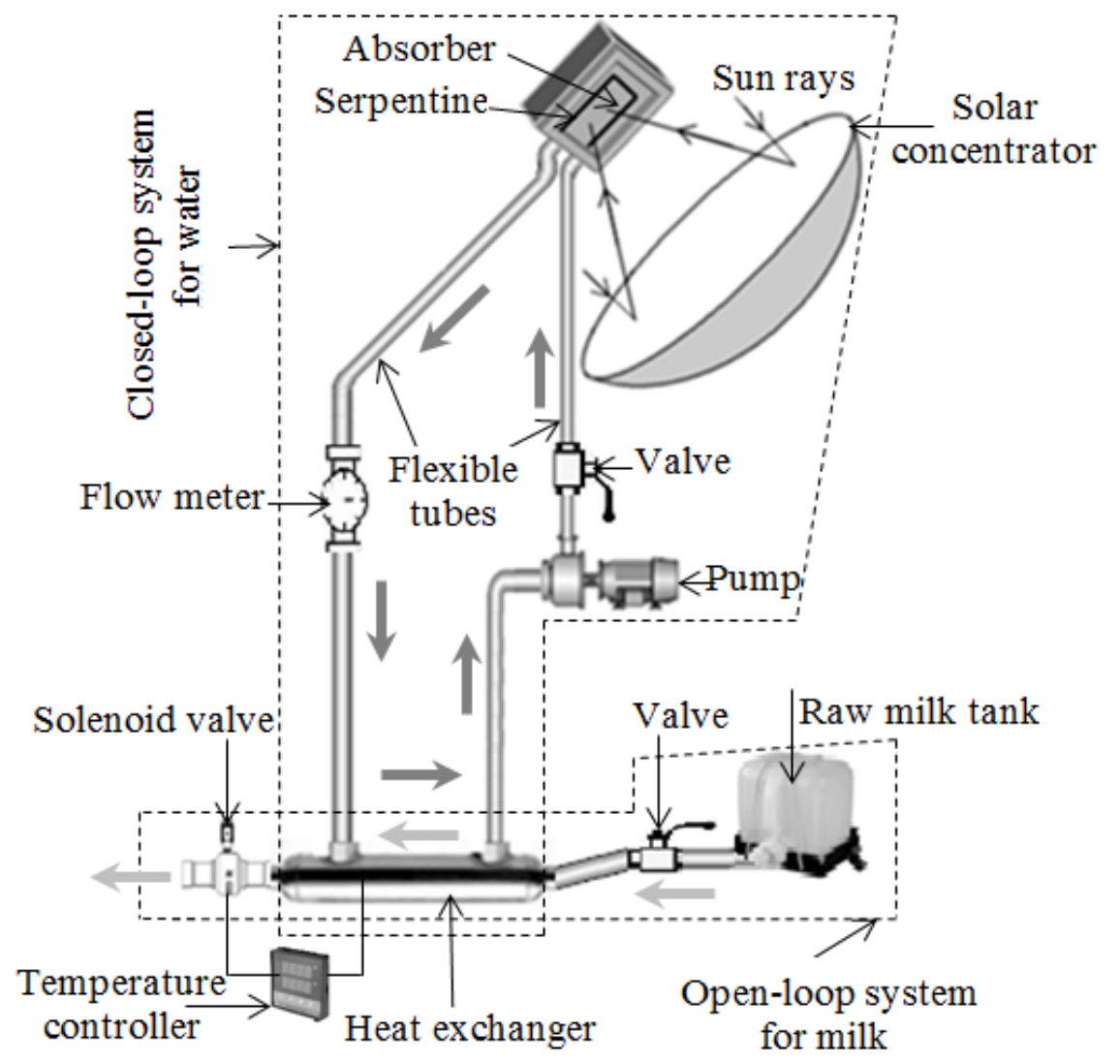

Fig. (7): Schematic of milk pasteurization by solar energy. 


\section{Sun tracking device:}

The tracking system was planned to be a low cost, simple, and accurate to follow the sun automatically in dual axis; the elevation and azimuth angles. As shown in Fig. (8), it consists of an electronic circuit sensing the sunlight then commands a motor which moving the solar concentrator. The method of sun-tracking and the parts of tracking system are illustrated as follow.

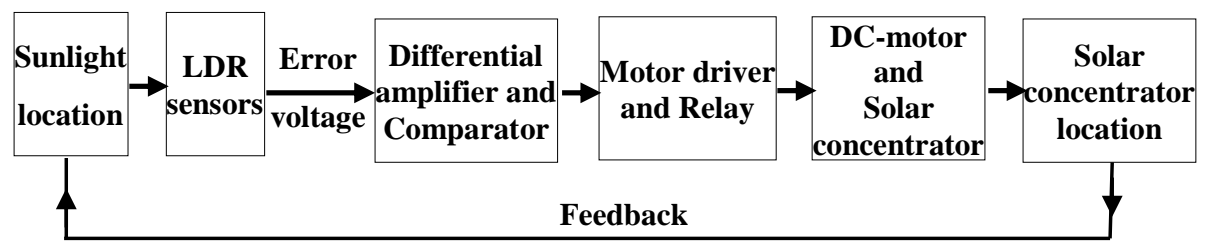

Fig. (8): Block diagram of sun-tracking system.

Two linear actuator motors (run forward and backward) (SuperJack, 24 inch, $36 \mathrm{~V}, 2 \mathrm{~A}$ ) were utilized to move the solar concentrator dish in dual axis, one of both for elevation (up-down), and the other for azimuth (eastwest). The solar concentrator dish and actuator motors are mounted over a couple of stand with a central movable axis.

An electronic circuit was developed and employed to sensing any change in sun position then commands the actuator motors. It can be divided to four units as shown in Fig. (9); sensing unit, processing unit, motor driving unit, and motor powering unit. Two sets of the circuit were used for tracking in dual axis.

Four light-dependent resistors (LDRs) were utilized for sensing the sunlight levels, two LDRs for each axis. LDRs are mounted over panel on the back of the absorber faced to sun and separated by obstacle which casts a shadow to increase the sensitivity.

The changes of the sun position produce a differential change in the output signals of each LDR. LDRs were connected to the inputs of the operational amplifier (op-amp) U1 and U2. Op-amp amplifies and interprets LDR's signal. As long as the sunlight levels over the two LDRs (for each axis) are uniform, the outputs of the op-amp are deactivated.

When the sun position is changed, the LDRs sense a different level of sunlight, thus the balance of the inputs of the op-amp shift toward the 
LDR which receives a higher level of sunlight, immediately the output of the relevant op-amp becomes HIGH (+). Once the sunlight level over the LDRs is restored uniform, the op-amp again becomes deactivated.

The HIGH (+) output activates the full bridge transistor Q1, Q2, Q3, and Q4 which operates the relays to enable the voltage and current for the actuator motor, thus the motor moves the solar concentrator and adjusts its alignment with the sun.

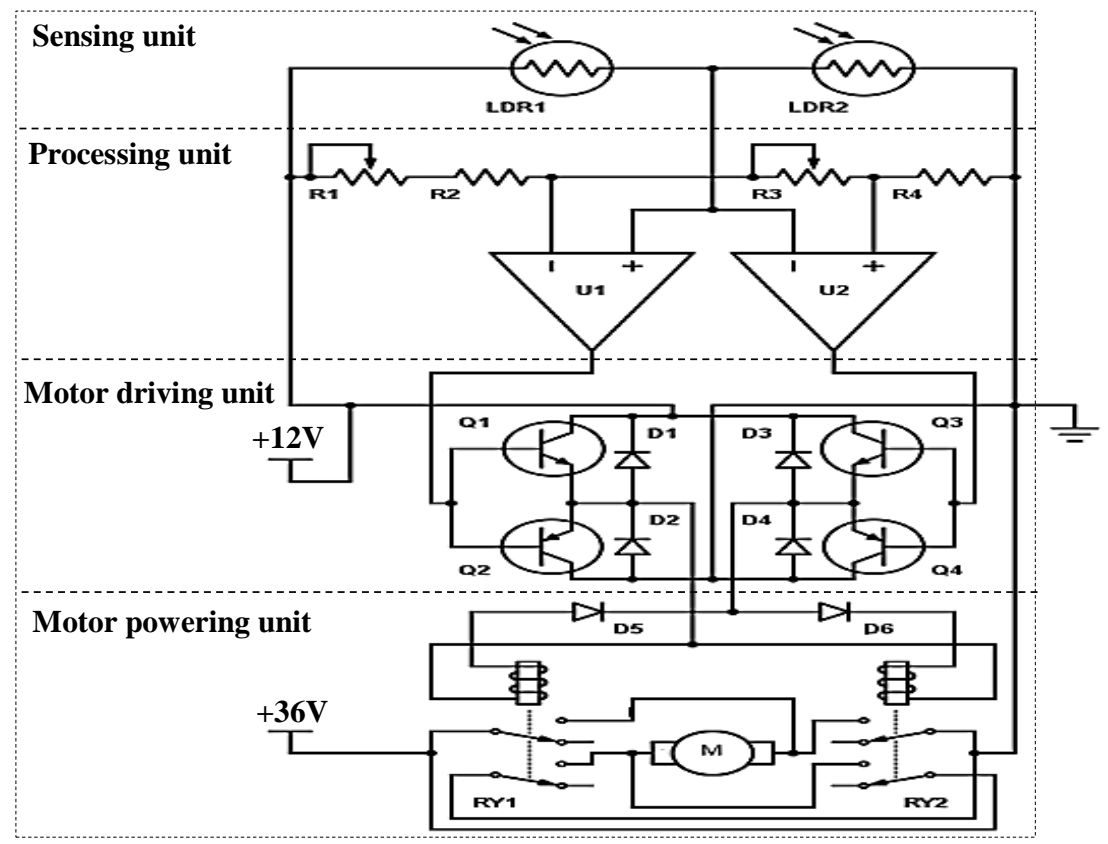

Fig. (9): Schematic of the electronic circuit of sun-tracking device.

\section{The measurements:}

The experiments were carried out from 10 AM to 2 PM at different weather conditions. Parameters measured included; temperature of milk inside the heat exchanger, temperature of water at inlet, inside and outlet of the heat exchanger and at inlet and outlet of the absorber, temperature of the absorber plate, ambient air temperature, solar radiation, water flow rate, elevation and azimuth angles of the concentrator.

The temperatures were measured (in $\mathrm{C}^{\circ}$ ) every 15 minutes by thermocouples (type k) which were coupled to digital thermometer. Solar radiation was measured by digital pyranometer (in $\mathrm{W} / \mathrm{m}^{2}$ ). The elevation 
and azimuth angles was measured by an android applications called Clinometer and Magnetmeter (available from plaincode company).

\section{RESULTS AND DISCUSSION}

\section{Sun tracking device test:}

The performance of the system equipped tracking device was compared with that obtained of the fixed system (non-tracking) which was tilted at fixed elevation angle $56^{\circ}$ towards the south.

Fig. (11) shows the average results of the temperature of absorber with the two techniques. With the fixed system, the minimum temperature of absorber still low then increases dramatically at noon in due to the absorber is in the focal zone then the temperature decreases again afternoon, the maximum and minimum temperature by this technique was 23 and $91{ }^{\circ} \mathrm{C}$ at respectively. While with the automatic tracking, the temperature of absorber approximately was in continuous increasing during the daylight hours, the maximum and minimum temperature by this technique was 101 and $190{ }^{\circ} \mathrm{C}$ at respectively.

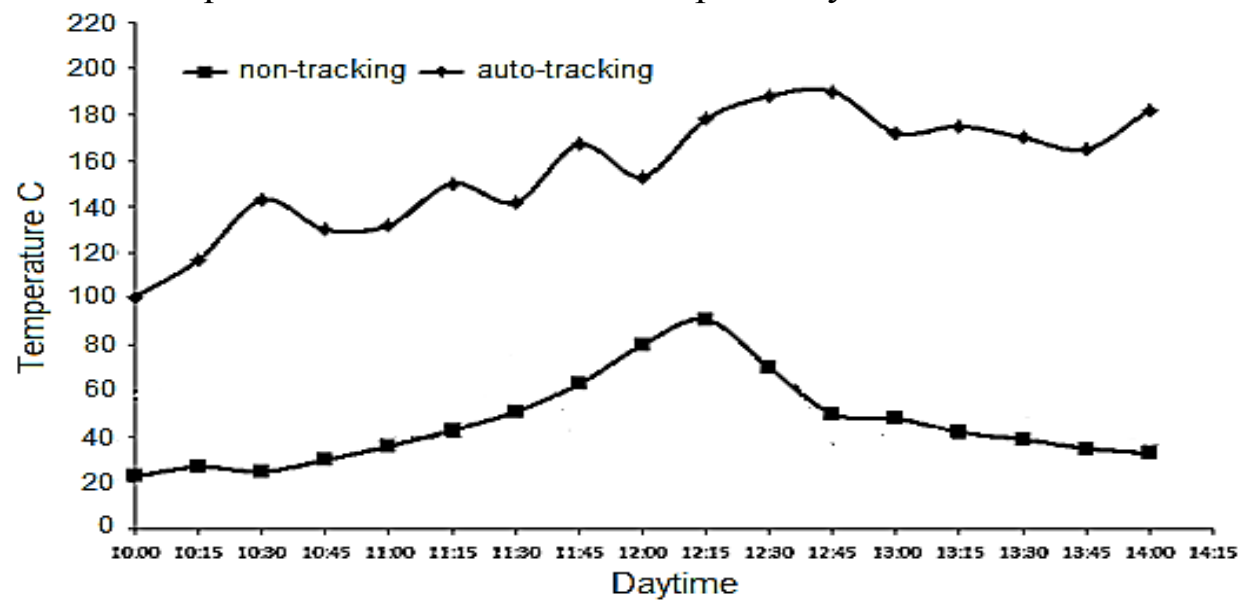

Fig. (11): Temperature of absorber with non-tracking and auto-tracking.

Fig. (12) shows the average cumulative heat energy with the two techniques. With the fixed system, the cumulative heat energy has one top and two bottoms, it increases dramatically at noon then it decreases again afternoon, the maximum and minimum cumulative heat energy by this technique was 12.5 and $142 \mathrm{~kJ} / \mathrm{kg}$ at respectively. While with the automatic tracking, the cumulative heat energy was in continuous 
increasing during the daylight hours, the maximum and minimum cumulative heat energy by this technique was 79 and $346 \mathrm{~kJ} / \mathrm{kg}$ at respectively.

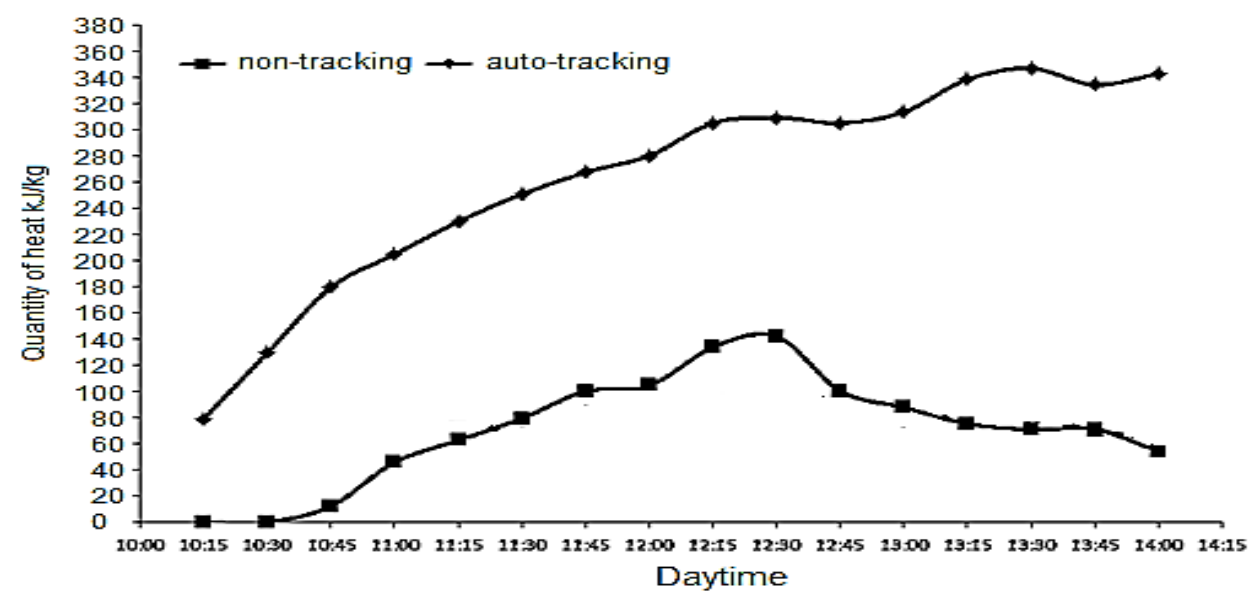

Fig. (12): the cumulative heat with non-tracking and auto-tracking.

In order to investigate the sun tracking device accuracy a comparative study of the experimental and the numerical angles (elevation and azimuth) has been done as shown in Fig. (13). The values of the experimental angles exhibited a good agreement with the values of the numerical angles. The error percentage between the experimental and the numerical values of azimuth ranged from 0 to $16 \%$, while it ranged from 0 to $6 \%$ for elevation angles. The error perhaps due to the absorber was not aligned properly, as well as the error of measuring.

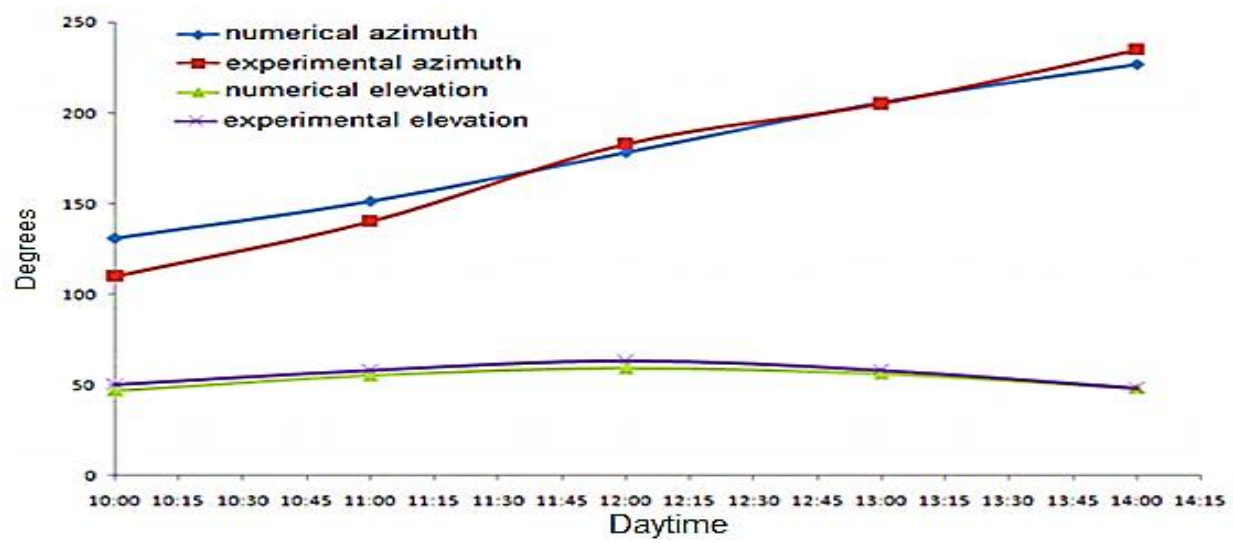

Fig. (13): Comparison of the experimental and the numerical angles. 


\section{The thermal performance:}

Fig. (14) represents the variation of the parameters; absorber temperature, inside heat exchanger temperature, and solar radiation as function of time using the sun-tracked system. Solar radiation was almost stable; it ranged in short range from 850 to $1020 \mathrm{~W} / \mathrm{m}^{2}$ in due to using sun tracking. The temperature of the absorber was in increasing with time, the fluctuation in the temperatures is a result to wind effect on the absorber. The temperature inside the heat exchanger was in increasing with fluctuation may be not mentioned, so that the heat exchanger can be a heat storage reservoir. The difference between the temperature of absorber and the temperature of heat exchanger is due to heat losses.

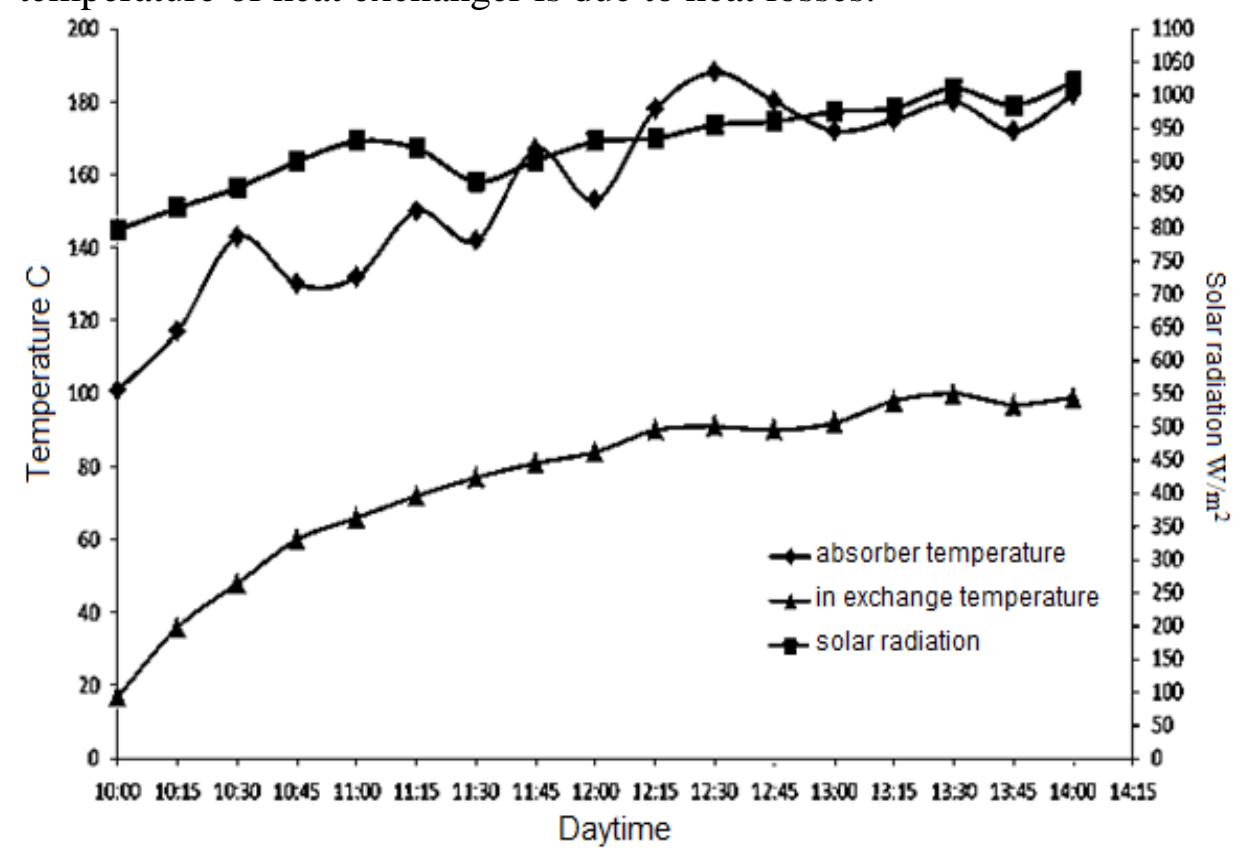

Fig. (14): The measured values of hourly variation of absorber temperature, inside heat exchanger temperature, and solar radiation.

Fig. (15) illustrates the scenario of temperature variation between the absorber and the heat exchanger as a function of time. It's clearly the temperature of water was raised at outlet of absorber in due to heat absorbing from the absorber, then the temperature was dropped inside the heat exchanger in due to the mixing of the hot water and the cooler water in the heat exchanger. The difference of temperature $\Delta \mathrm{T}$ of the heat 
exchanger has high value at the start of heating process then it drops consistent with the rise of temperature, that is due to the increasing of water specific heat with the increasing of water temperature.

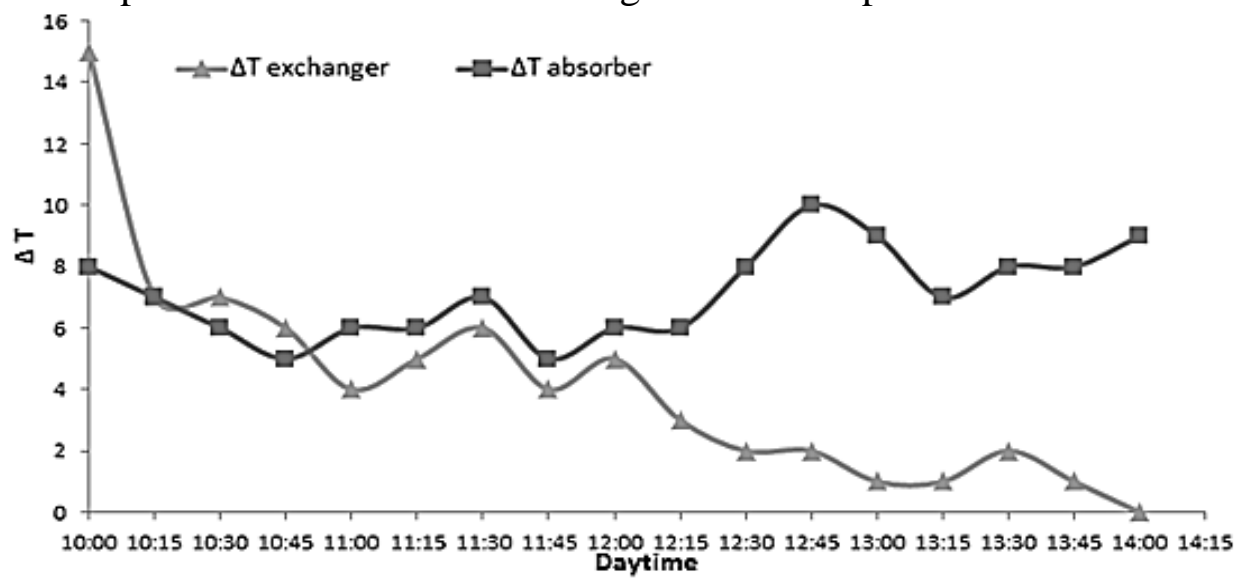

Fig. (15): $\Delta \mathrm{T}$ profile of heat transfer scenario between the absorber and the heat exchanger.

\section{Milk pasteurization by solar concentrator:}

The temperature of water in the heat exchanger reached $90{ }^{\circ} \mathrm{C}$ in about two hours from the start of solar heating process. Then the milk starts to flow inside the heat exchanger, as shown in Fig. (16) the milk reached to the pasteurization temperature $73{ }^{\circ} \mathrm{C}$ in average time 110 seconds. The average quantity of solar pasteurized milk was 7.5 liters per hour.

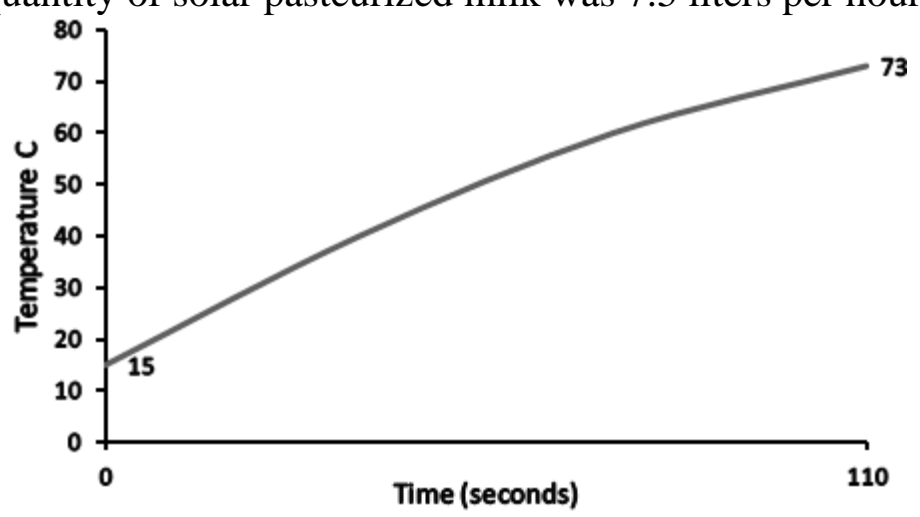

Fig. (16): Average time for milk pasteurization by the system.

\section{CONCLUSSION}

This investigation introduced the construction, operation, and the test results of a solar concentrator with dual axis sun tracking utilizing for 
milk pasteurization. Modified satellite dish was employed as a solar concentrator. The process of milk pasteurization partitioned into two separated loops; one of both is for water heating by solar energy, the other one is for milk heating by hot water, the two loops become in contact by a heat exchanger.

The conclusions of this investigation are:

1. The tracked system achieved the pasteurization temperature in average time 110 seconds depending on the average solar intensity;

2. The average hourly quantity of solar-pasteurized milk by the tracked solar-pasteurizer is 7.5 liters;

3. Using the sun tracking device was led to increase of the cumulative daily heat gain by approximately $59 \%$.

It can be recommended that:

1- Improving the performance of the absorber by covering it with glass.

2- Use of such designed system to pasteurize water and juices.

\section{REFERENCES}

ASHRAE (1995). Handbook of HVAC Applications, ch. 30, Atlanta, GA, USA.

ASHRAE (2005). Handbook of Fundamentals, American Society of Heating, Refrigerating and Air Conditioning Engineers, New York.

Atia, M. F., Mostafa, M. M., Abdel-Salam, M. F., and El-Nono, M. A. (2010). Solar energy utilization for milk pasteurization., M.Sc. th. Agric. Eng. Dept., Fac. of Agric., Ain Shams Univ., Egypt.

Bergman, T. L., Incropera, F. P., and Lavine, A. S. (2011). Fundamentals of heat and mass transfer. John Wiley \& Sons.

Bairi, A. (1990). Method of quick determination of the angle of slope and the orientation of solar collectors without a sun tracking system. Solar Wind Technol. 7, 327-330.

Braun J. E. and Mitchell J. C. (1983). Solar geometry for fixed and tracking surfaces. Solar Energy;31(5):439-44.

El-Shebley, M.; Ahmed, H. S. and Hetr R. F. (2003). The development of production, processing and marketing to small-scale dairy 
farmers in the Arab world, AOAD, Arab Organization for Agricultural Development, Sudan.

Franco, J.; Saravia, L.; Javi, V.; Ricardo, C. and Carlos F. (2007). Pasteurization of goat milk using a low cost solar concentrator, Solar Energy J., doi:10.1016/j.solener.2007.10.011, USA.

Kalogirou S., Eleftheriou P., Lloyd S., and Ward J. (1994). Design and performance characteristics of a parabolic-trough solar collector system. Appl Energy;47:341-54.

Kalogirou, S. A. (2004). Solar thermal collectors and applications, Progress in Energy and Combustion Science, 30: 231-295.

Lee, C. Y., Chou, P. C., Chiang, C. M., and Lin, C. F. (2009). Sun tracking systems: a review. Sensors, 9(5), 3875-3890.

Mousazadeh, H., Keyhani, A., Javadi, A., Mobli, H., Abrinia, K., and Sharifi, A. (2009). A review of principle and sun-tracking methods for maximizing solar systems output. Renewable and sustainable energy reviews, 13(8), 1800-1818.

Niamsuwan, S., Kittisupakorn, P., and Mujtaba, I. M. (2011). Optimization approach to minimize energy consumption in pasteurized milk process. International Conference on Chemistry and Chemical Process. Bangkok, Thailand, May 28; 29.

Rauta S. and Singh N., (2009), Non-Conventional energy sources, Department of Electrical Engineering, National Institute of Technology, Rourkela, India. 47-54

Sorensen, B. (2003). Renewable Energy Its physics, engineering, use, environmental impacts, economy and planning aspects, $3^{\text {rd }}$ Elsevier Academic Press, Roskilde Univ., Energy \& Environment Group, Ins. 2, Denmark.

Wayua, F. O., Okoth, M. W., and Wangoh, J. (2013). Design and performance assessment of a flat-plate solar milk pasteurizer for arid pastoral areas of kenya. Journal of Food Processing and Preservation, 37(2), 120-125.

William, B. and Raymond, W. (1985). Solar energy fundamentals and design, John Wiley \& Sons, New York, USA.

Zahira, R.; Hafiz, A.; Nasir, A.; Muhammad, A. and Zia-ul-Haq (2009). fabrication and performance study of a solar milk pasteurizer, J. Agri. Sci., Pakistan Vol. 46(2). 


\section{الملخص العربـى}

\section{بسترة اللبن باستخدام مركِز شمسي مزود بجهاز لتعقب الشمس}

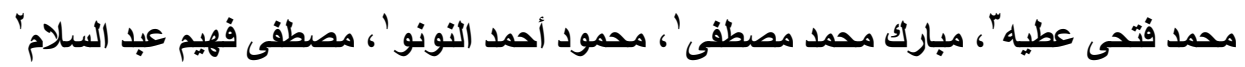

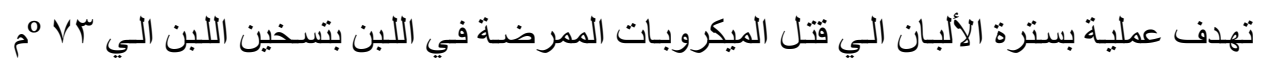

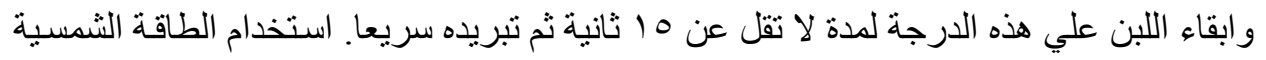

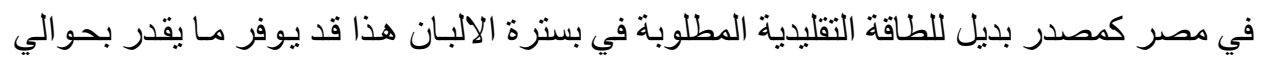

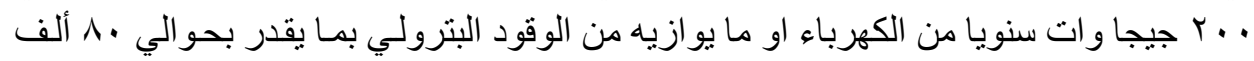

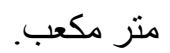

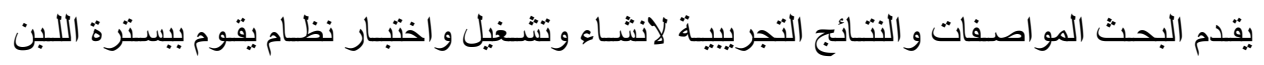

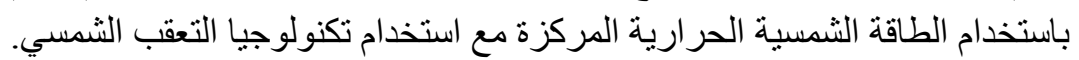

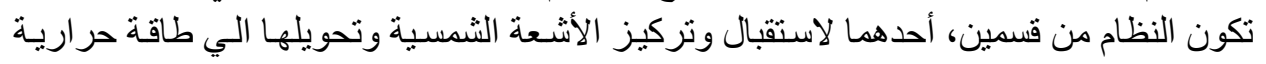

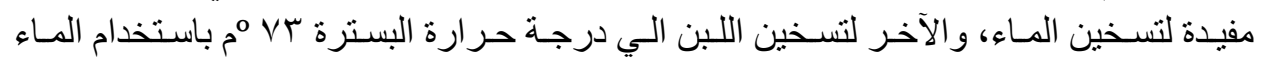

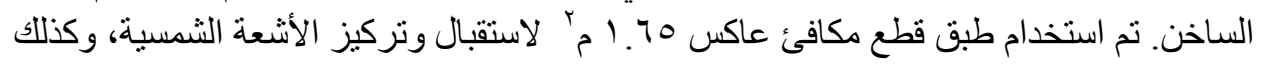
مبادل حر ارى أنبوبي لتنخين اللبن.

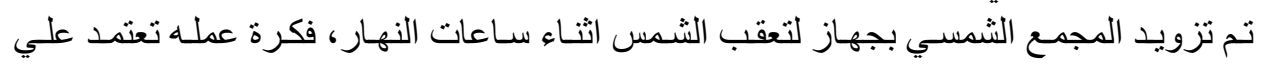

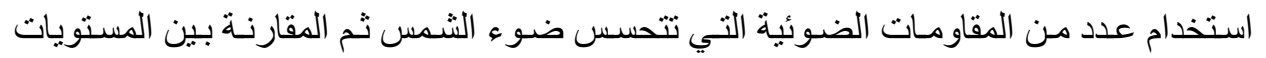

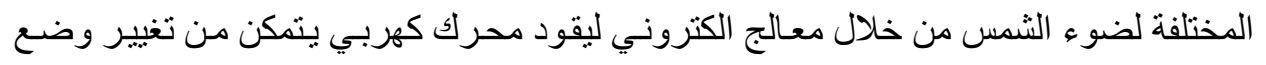
المجمع الثمسي طبقا لوضع الثن الثمس. أجريت التجارب في كلية الزر اعة، جامعة عين شمس، شبرا الشئ الخيمة، مصر. عند قيم مختلفة من درجات حرارة الجو و الاشعاع الثمسي. وكانت أهم النتائج الدتحصل والأنعاع اليها من الدراسة التجريبية:

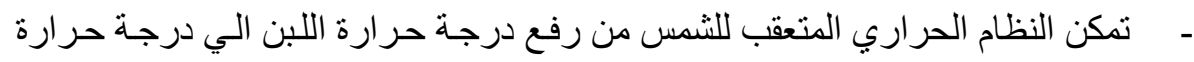
البسترة في زمن متوسط يقدر بحو الي ، ل1 1 أثانية.

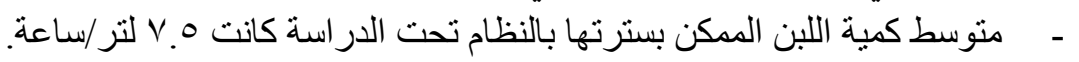

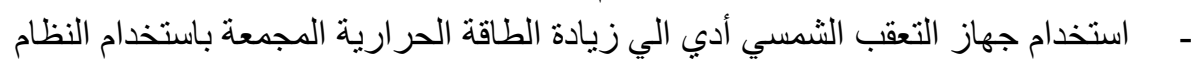

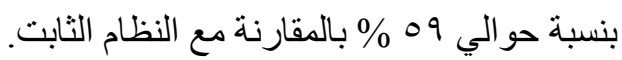

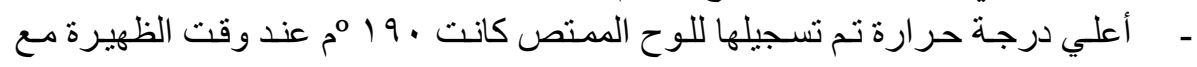

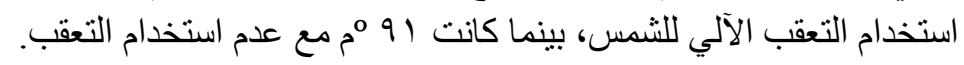

'ـ ' أستاذ متفرغ ـ قسم الهندسة الزراعية، كلية الزراعة، جامعة عين شمس.

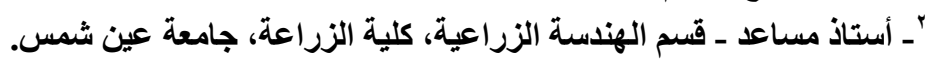

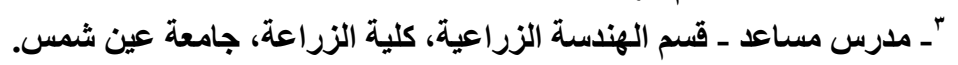

